\title{
tanter \\ Palaeoecological Analysis and Diversity of Turtles and Other Reptiles
}

\author{
Adán Pérez-García
}

check for

updates

Citation: Pérez-García, A.

Palaeoecological Analysis and Diversity of Turtles and Other Reptiles. Diversity 2022, 14, 88. https://doi.org/10.3390/d14020088

Received: 11 January 2022

Accepted: 17 January 2022

Published: 27 January 2022

Publisher's Note: MDPI stays neutral with regard to jurisdictional claims in published maps and institutional affiliations.

Copyright: (C) 2022 by the author. Licensee MDPI, Basel, Switzerland. This article is an open access article distributed under the terms and conditions of the Creative Commons Attribution (CC BY) license (https:// creativecommons.org/licenses/by/ $4.0 /)$.
Grupo de Biología Evolutiva, Facultad de Ciencias, Universidad Nacional de Educación a Distancia, Avda. Esparta s/n, Las Rozas, 28232 Madrid, Spain; a.perez.garcia@ccia.uned.es

Reptilia is a very successful monophyletic clade of vertebrates (i.e., including birds but not sinapsids), with a wide morphological disparity, representing one of the most remarkable components of the extant biodiversity [1]. Non-avian reptiles are currently represented by more than 9000 species. They have adapted to numerous and highly diverse terrestrial and aquatic environments. Thus, many lifestyles have been recognized, including taxa inhabitants of arid land regions, but also of oceanic ones [2]. Its fossil record, especially that of the Mesozoic representatives (i.e., those that lived in the era generally known as 'the age of reptiles'), shows a remarkable diversity and disparity [3-6].

Turtles (i.e., the members of Testudinata) represent a diverse lineage of reptiles (see [7] and references therein). Although turtles have traditionally been considered anapsid reptiles, they are generally recognized as diapsids today [8]. There is currently no consensus on whether they are more closely related to the lepidosaurs (being part of the clade Ankylopoda; see [9] and references therein) or to the archosaurs (constituting the clade Archelosauria; see [10] and references therein) [11]. The oldest evidence of the lineage that gives rise to turtles has been recognized in middle Permian levels, deposited more than 260 million years ago [12]. These taxa, likely of terrestrial habitats, had a diapsid skull. Their evolution produced the loss of the temporal fossae, resulting in a cranial appearance convergent with that of anapsid reptiles [13]. Since the Late Triassic, members of the Testudinata have been characterized by a conservative Bauplan, in which the presence of a shell is characteristic, constituted with a dorsal element (the carapace) and a ventral area (the plastron) [14,15].

Two lineages of turtles, both with extant representatives, are recognized from the Late Jurassic to the Present: Pan-Pleurodira and Pan-Cryptodira [11,16]. Turtles, especially the members of Pan-Cryptodira, are adapted to many environments, including marine, freshwater, and terrestrial ones. They are represented by about 350 species forming part of the current biodiversity [7]. As with some other reptile lineages, the diversity and disparity of turtles in the past, especially during the Cretaceous, were greater than today [17,18]. Thus, the fossil record not only allows us to identify many extinct taxa and lineages belonging to the two clades that compose the crown group Testudines, but also numerous basal forms are recognized. In this sense, turtles are one of the best represented tetrapod lineages in the vertebrate fossil sites [16]. This is due both to its adaptation to different environments and lifestyles, as well as to the robustness of the shell and the plates that compose it.

Knowledge about the origin and evolutionary history of the turtles has increased notably during the last few decades and especially over this first part of the 21st century. Thus, in addition to the description of new taxa and of the review of previously defined ones, recent works showing the compilation and updating of the fossil record of specific turtle lineages (see, among others, [19] for bothremydids, [20] for podocnemidids, [21] for chelids, [22] for chelydrids, [23,24] for trionychids, and [25] for thalassochelydians), as well as those analyzing the diversity and evolutionary history of the turtles from wide-ranging regions (e.g., those of South America, see [26]; or Europe, see [16,27]) are relevant to identify and elucidate the diversity and evolutionary history of this lineage. However, in addition to these works based mainly on anatomical descriptions and systematic discussions, there 
are also others that offer results obtained through the application of more innovative methodologies or techniques scarcely applied for the study of this lineage. Thus, new turtle taxa, but also others that have previously been identified, have been characterized with great precision by, for example, the application of non-invasive scanning techniques to carry out neuroanatomical studies (e.g., [28]) or the characterization of shell anomalies (e.g., [29]). In this sense, the first detailed neuroanatomical study performed for a member of Bothremydidae (i.e., a successful lineage of pleurodiran turtles that lived in most continents of both Laurasia and Gondwana, from the Cretaceous to the Paleogene) has been published in this Special Issue [30]. In addition, one of the first detailed studies on extreme cases of morphological variation corresponding to anomalies in basal turtles (i.e., stem Testudines) has also been published here, based on the study of numerous specimens of a single species belonging to the Pleurosternidae clade [31]. Similar to the increase in knowledge of that in Testudinata, combining the application of traditional and other more innovative methodologies has also been developed as a strategy, during the last few decades, for the analysis of other lineages of non-avian reptiles. This is the case, for example, for crocodiles and dinosaurs (e.g., [32,33]). However, the application of more traditional systematic studies is also essential for the development of paleontology. In this context, a paper analyzing material attributable to the first genus of dinosaur that was defined (i.e., Iguanodon) has also been published in this Special Issue; new data on its anatomy, diversity and geographic distribution are provided [34].

This Special Issue provides new data on the diversity, evolutionary history, anatomy, temporal and biogeographical distributions, lifestyle, and paleoecology of several taxa of reptiles, especially belonging to Testudinata. Particularly relevant are the works that analyze the systematics, variability, and diversity of extinct taxa, as well as those in which their sensory capabilities and palaeoecological roles have been studied.

Conflicts of Interest: The author declares no conflict of interest.

\section{References}

1. Pincheira-Donoso, D.; Bauer, A.M.; Meiri, S.; Uetz, P. Global Taxonomic Diversity of Living Reptiles. PLoS ONE 2013,8 , e59741.

2. Shine, R. Life-history evolution in reptiles. Annu. Rev. Ecol. Systemat. 2005, 36, 23-46. [CrossRef]

3. Bardet, N.; Falconnet, J.; Fischer, V.; Houssaye, A.; Jouve, S.; Pereda Suberbiola, X.; Pérez-García, A.; Rage, J.-C.; Vincent, P. Mesozoic marine reptile palaeobiogeography in response to drifting plates. Gondwana Res. 2014, 26, 869-887. [CrossRef]

4. Stubbs, T.; Benton, M. Ecomorphological diversifications of Mesozoic marine reptiles: The roles of ecological opportunity and extinction. Paleobiology 2016, 42, 547-573. [CrossRef]

5. Simões, T.R.; Vernygora, O.; Caldwell, M.W.; Pierce, S.E. Megaevolutionary dynamics and the timing of evolutionary innovation in reptiles. Nat. Commun. 2020, 11, 3322. [CrossRef] [PubMed]

6. Foth, C.; Sookias, R.B.; Ezcurra, M.D. Rapid initial morphospace expansion and delayed morphological disparity peak in the first 100 million years of the archosauromorph evolutionary radiation. Front. Earth Sci. 2021, 9, 723973. [CrossRef]

7. Rhodin, A.G.J.; Iverson, J.B.; Bour, R.; Fritz, U.; Georges, A.; Shaffer, H.B.; van Dijk, P.P. Turtles of the World: Annotated Checklist and Atlas of Taxonomy, Synonymy, Distribution, and Conservation Status (9th Ed.). Chelonian Res. Monog. 2021, 8, 1-472.

8. Schoch, R.R.; Sues, H.-D. The diapsid origin of turtles. Zoology 2016, 119, 159-161. [CrossRef]

9. Lyson, T.R.; Sperling, E.A.; Heimberg, A.M.; Gauthier, J.A.; King, B.L.; Peterson, K.J. MicroRNAs support a turtle + lizard clade. Biol. Lett. 2012, 8, 104-107. [CrossRef]

10. Crawford, N.G.; Parham, J.F.; Sellas, A.B.; Faircloth, B.C.; Glenn, T.C.; Papenfuss, T.J.; Henderson, J.B.; Hansen, M.H.; Simison, W.B. A phylogenomic analysis of turtles. Mol. Phylogenet. Evol. 2015, 83, 250-257. [CrossRef]

11. Joyce, W.G.; Anquetin, J.; Cadena, E.A.; Claude, J.; Danilov, I.G.; Evers, S.W.; Ferreira, G.S.; Gentry, A.D.; Georgalis, G.J.; Lyson, T.R.; et al. A nomenclature for fossil and living turtles using phylogenetically defined clade names. Swiss J. Palaeontol. 2021, 140, 5. [CrossRef]

12. Lyson, T.R.; Bever, G.S. Origin and evolution of the turtle body plan. Annu. Rev. Ecol. Evol. Systemat. 2020, 51, 143-166. [CrossRef]

13. Schoch, R.R.; Sues, H.-D. The origin of the turtle body plan. Palaeontology 2020, 63, 375-393. [CrossRef]

14. Gaffney, E.S. The comparative osteology of the Triassic turtle Proganochelys. Bull. Am. Mus. Nat. Hist. 1990, 194, 1-263.

15. Li, C.; Fraser, N.C.; Rieppel, O.; Wu, X.-C. A Triassic stem turtle with an edentulous beak. Nature 2018, 560, 476-479. [CrossRef]

16. Pérez-García, A. The Iberian fossil record of turtles: An update. J. Iber. Geol. 2017, 43, 155-191. [CrossRef]

17. Foth, C.; Joyce, W.G. Slow and steady: The evolution of cranial disparity in fossil and recent turtles. Proc. R. Soc. B 2016, 283, 20161881. [CrossRef] 
18. Colston, T.J.; Kulkarni, P.; Jetz, W.; Pyron, R.A. Phylogenetic and spatial distribution of evolutionary diversification, isolation, and threat in turtles and crocodilians (non-avian archosauromorphs). BMC Evol. Biol. 2020, 20, 81. [CrossRef]

19. Gaffney, E.S.; Tong, H.; Meylan, P.E. Evolution of the side-necked turtles: The families Bothremydidae, Euraxemydidae, and Araripemydidae. Bull. Am. Mus. Nat. Hist. 2006, 300, 1-698. [CrossRef]

20. Gaffney, E.S.; Meylan, P.A.; Wood, R.G.; Simons, E.; de Almeida Campos, D. Evolution of the side-necked turtles: The family Podocnemididae. Bull. Am. Mus. Nat. Hist. 2011, 350, 1-237. [CrossRef]

21. Maniel, I.J.; de la Fuente, M.S. A review of the fossil record of turtles of the clade Pan-Chelidae. Bull. Peabody Mus. Nat. His. 2016, 57, 191-227. [CrossRef]

22. Joyce, W.G. A review of the fossil record of turtles of the clade Pan-Chelydridae. Bull. Peabody Mus. Nat. His. 2016, 57, 21-56. [CrossRef]

23. Georgalis, G.L.; Joyce, W.G. A review of the fossil record of Old Word turtles of the clade Pan-Pan-Trionychidae. Bull. Peabody Mus. Nat. His. 2017, 58, 115-208. [CrossRef]

24. Vitek, N.S.; Joyce, W.G. A review of the fossil record of New Word turtles of the clade Pan-Pan-Trionychidae. Bull. Peabody Mus. Nat. His. 2015, 56, 185-244. [CrossRef]

25. Anquetin, J.; Püntener, C.; Joyce, W.G. A review of the fossil record of turtles of the clade Thalassochelydia. Bull. Peabody Mus. Nat. His. 2017, 58, 317-369. [CrossRef]

26. de la Fuente, M.S.; Sterli, J.; Maniel, I. Origin, Evolution and Biogeographic History of South American Turtles; Springer: New York, NY, USA, 2014; pp. 1-169.

27. de Lapparent de Broin, F. The European turtle fauna from the Triassic to the Present. Dumerilia 2001, 4, 155-216.

28. Paulina-Carabajal, A.; Sterli, J.; Müller, J.; Hilger, A. Neuroanatomy of the marine Jurassic turtle Plesiochelys etalloni (Testudinata, Plesiochelyidae). PLoS ONE 2013, 8, e69264. [CrossRef]

29. Cherepanov, G.O. Nature of the turtle shell: Morphogenetic causes of bone variability and its evolutionary implication. Paleontol. J. 2016, 50, 1641-1648. [CrossRef]

30. Martín-Jiménez, M.; Pérez-García, A. Neuroanatomical study and three-dimensional reconstruction of the skull of a bothremydid turtle (Pleurodira) based on the European Eocene Tartaruscola teodorii. Diversity 2021, 13, 298. [CrossRef]

31. Guerrero, A.; Pérez-García, A. Shell anomalies in the European aquatic stem turtle Pleurosternon bullockii (Paracryptodira,.Pleurosternidae). Diversity 2021, 13, 518. [CrossRef]

32. Holliday, C.M.; Witmer, L.M. The epipterygoid of crocodyliforms and its significance for the evolution of the orbitotemporal region of eusuchians. J. Vertebr. Paleontol. 2009, 29, 715-733. [CrossRef]

33. Witmer, L.M.; Ridgely, R.C. The Cleveland tyrannosaur skull (Nanotyrannus or Tyrannosaurus): New findings based on CT Scanning, with special reference to the braincase. Kirtlandia 2010, 57, 61-81.

34. Gasulla, J.M.; Escaso, F.; Narváez, I.; Sanz, J.L.; Ortega, F. New Iguanodon bernissartensis axial bones (Dinosauria, Ornithopoda) from the Early Cretaceous of Morella, Spain. Diversity 2022, 14, 63. [CrossRef] 